\title{
Expression of estrogen receptors and androgen receptor and their clinical significance in gastric cancer
}

\author{
Wenbo Tang ${ }^{1,2, *}$, Rujiao Liuu, ${ }^{1,2}$, , Yan Yan ${ }^{1,2, *}$, Xiaoli Pan ${ }^{3}$, Minjun Wang ${ }^{4}$, Xiaotian \\ Han $^{2,5}$, Hui Ren ${ }^{6}$ and Zhe Zhang ${ }^{1,2}$ \\ ${ }^{1}$ Department of Medical Oncology, Fudan University Shanghai Cancer Center, Shanghai, P.R. China \\ ${ }^{2}$ Department of Oncology, Shanghai Medical College, Fudan University, Shanghai, P.R. China \\ ${ }^{3}$ Department of Neurology, Zhongshan Hospital, Fudan University, Shanghai, P.R. China \\ ${ }^{4}$ Shanghai Key Laboratory of Bioactive Small Molecules, Department of Pharmacology, School of Pharmacy, Fudan University, \\ Shanghai, P.R. China \\ ${ }^{5}$ Department of Gynecologic Oncology, Fudan University Shanghai Cancer Center, Shanghai, P.R. China \\ ${ }^{6}$ Department of Breast Surgery, Lanzhou General Hospital, Lanzhou, P.R. China \\ *These authors have contributed equally to the work \\ Correspondence to: Zhe Zhang, email: zhangzhe2010fduscc@gmail.com \\ Keywords: gastric cancer, estrogen receptor, androgen receptor, epithelial-mesenchymal transition \\ Received: April 04, $2016 \quad$ Accepted: March 13, $2017 \quad$ Published: March 28, 2017 \\ Copyright: Tang et al. This is an open-access article distributed under the terms of the Creative Commons Attribution License 3.0 \\ (CC BY 3.0), which permits unrestricted use, distribution, and reproduction in any medium, provided the original author and source \\ are credited..
}

\section{ABSTRACT}

Despite the mounting studies exploring the role of estrogen receptor alpha (ERa), estrogen receptor beta (ERß) and androgen receptor (AR) in gastric cancer (GC), there remain controversies in those findings. The present study investigated the expression of ERa, ER $\beta$ and AR in Chinese gastric cancer by immunohistochemistry, analyzed their clinical relevance in gastric cancer, and examined the potential mechanisms by which ERa and AR modulated GC progression. The positive rate of ERa, ERB and AR in GC tissues was $6 \%(9 / 150), 93.5 \%(143 / 153)$, and $42.4 \%(59 / 139)$, respectively. The expression of ERa was an independent unfavorable risk factor for overall survival (OS) (hazard ratio $[\mathrm{HR}]=3.639,95 \%$ confidence interval $[\mathrm{CI}]=1.432-9.246, p=0.007$ ) for GC patients. Moreover, AR was borderline significantly associated with poor progress free survival (PFS) after adjustment with other variables (HR $=1.573,95 \% \mathrm{CI}=0.955$ 2.592, $p=0.075$ ). Knockdown of ERa inhibited the proliferation, migration and invasion of GC cells possibly via modulating the expression of p53, p21, p27, cyclin D1 and E-cadherin. Downregulation of AR suppressed the migration and invasion of GC cells and inhibited the epithelial-mesenchymal transition (EMT) associated pathways.

Conclusion: The present study showed that positive ERa was associated with poor prognosis of Chinese GC patients. ERa might modulate the proliferation, migration and invasion via regulating the expression of p53, p21, p27, cyclin D1 and E-cadherin. ERa could be a valuable prognostic biomarker and promising therapeutic target for Chinese GC patients.

\section{INTRODUCTION}

Gastric cancer (GC) is the fifth most common cancer and the third leading cause of cancer-related death in the world [1]. A large number of patients are diagnosed with GC at advanced stage with poor prognosis. Even though progress has been achieved in recent years in the treatment of GC, the benefit is still modest. For example, trastuzumab combined with chemotherapy markedly improved the survival of patients with human epidermal 
growth factor receptor 2 (HER2)-positive metastatic GC, the median overall survival was only 13.8 months [2]. All these concerns illustrate an urgent need for novel therapies and biomarkers to help identify GC patients who will benefit from specific treatments.

In the past decades, hormonal therapy has been well established in the treatment of hormone-dependent tumors such as prostate cancer and breast cancer $[3,4]$. However, the role of hormone receptors in tumors located innontarget organs, including GC, remains largely unknown.

The relationship between hormone receptors and GC was first reported by Tokunaga et al [5]. Since then, mounting studies have investigated the expression of sex hormone receptors including estrogen receptor alpha $(E R \alpha)$, estrogen receptor beta $(E R \beta)$ and androgen receptor (AR), as well as their prognostic implications in GC [6-20]. However, the results remain inconclusive and controversial. For instance, some studies claimed that ER $\alpha$ was not expressed while ER $\beta$ was expressed abundantly in GC [10], whereas others showed that both receptors were expressed [7, 9, 11, 17, 18]. In addition, some studies indicated ER expression was associated with advanced stage and poor survival whereas others drew totally different conclusion [7, 14, 17, 18]. Besides, there were limited researches on the role of AR in GC [18-20]. The present study investigated the prognostic role and potential mechanisms of ER $\alpha, E R \beta$ and $\mathrm{AR}$ in GC patients of Chinese population, aiming to provide evidence justifying the possibility of ER $\alpha$ as a novel therapeutic target.

\section{RESULTS}

\section{$E R \alpha, E R \beta$ and AR expression in GC tissues}

The positive rate of $\mathrm{ER} \alpha, \mathrm{ER} \beta$ and $\mathrm{AR}$ in $\mathrm{GC}$ tissues was $6.0 \%$ (9/150), 93.5\% (143/153), and 42.4\% (59/139), respectively (Table 1$)$. Representative staining results of $\mathrm{ER} \alpha, \mathrm{ER} \beta$ and AR were presented in Figure 1, indicating the expression of the three receptors in both cytoplasm and nucleus. The correlations of $\mathrm{ER} \alpha, \mathrm{ER} \beta$ and AR expression were presented in Supplementary Table 1. The correlation coefficients of ER $\alpha$ and $E R \beta, E R \alpha$ and $A R$, and $E R \beta$ and AR expression were $0.275(p=0.001), 0.287(p=0.001)$, $0.388(\mathrm{p}<0.001)$, respectively.

\section{Association of ER $\alpha, E R \beta$ and AR expression with clinicopathological characteristics}

Clinicopathological characteristics including patient sex, age, whether received adjuvant chemotherapy, tumor grade, vascular and nerve invasion, TNM classification and stage of the patients enrolled in this study were listed in Table 1. Patients with resectable lesion received D2 resection. Among 129 patients received adjuvant chemotherapy, most received standard chemotherapy according to the NCCN guidelines of the year they undergone treatment (2007 to 2010), including XELOX regimen (capecitabine plus oxaliplatin), fluorouracil monotherapy, FOLFOX regimen (oxaliplatin plus fluorouracil), EOF regimen (epirubicin, oxaliplatin plus fluorouracil), and ECF regimen (epirubicin, cisplatin plus fluorouracil). As shown in Table 1, there was no significant association of $\mathrm{ER} \alpha$ or $\mathrm{ER} \beta$ expression with any of the clinicopathological characteristics. However, higher AR positive rate was observed in patients older than 58 years old (median age of the patients) compared to patients younger than 58 years old $(p=0.017)$. Moreover, higher AR expression was observed in patients with better differentiated tumors $(p=0.009)$.

\section{Positive expression of ER $\alpha$ was associated with unfavorable outcome in GC patients}

The median follow-up time for the patients was 48.5 months (range 24.7-70.1 months), and nine patients who failed to contact through telephone or email were lost to follow up. Kaplan-Meier survival curves for ER $\alpha, \operatorname{ER} \beta$ and AR expression were shown in Figure 2. Three-year

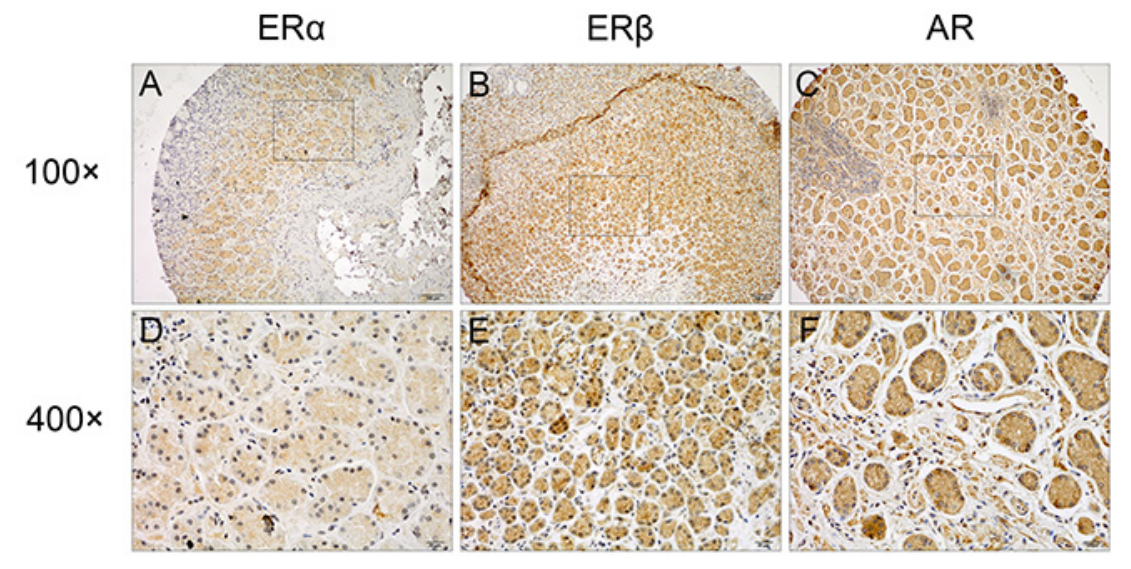

Figure 1: Representative immunostaining of ER $\alpha, E R \beta$ and $A R$ in $G C$ tissues. Positive staining of (A, D) ER $\alpha,(B, E) E R \beta$, and $(\mathbf{C}, \mathbf{F}) \mathrm{AR}$ in GC tumors were shown. Original magnification, $100 \times$ for $(\mathrm{A})$, (B) and (C), $400 \times$ for $(\mathrm{D}),(\mathrm{E})$ and $(\mathrm{F})$. 
Table 1: Association of expression of ER $\alpha, E R \beta$, and AR with clinicopathological characteristics in gastric cancer [n (\%)]

\begin{tabular}{|c|c|c|c|c|c|c|c|}
\hline \multirow{3}{*}{ Variable } & \multirow{3}{*}{$\begin{array}{l}\text { Total patients } \\
\qquad(n=155)\end{array}$} & \multicolumn{6}{|c|}{ Evaluable patients } \\
\hline & & \multicolumn{2}{|c|}{$\operatorname{ER\alpha }(n=150) *$} & \multicolumn{2}{|c|}{$\operatorname{ER} \beta(n=153) *$} & \multicolumn{2}{|c|}{$\operatorname{AR}(n=139) *$} \\
\hline & & $\begin{array}{l}\text { Positive } \\
\text { No. }(\%)\end{array}$ & $p$ & $\begin{array}{l}\text { Positive } \\
\text { No. }(\%)\end{array}$ & $p$ & $\begin{array}{l}\text { Positive } \\
\text { No. }(\%)\end{array}$ & $p$ \\
\hline \multicolumn{8}{|l|}{ Sex } \\
\hline Female & 38 & $2(5.4)$ & \multirow{2}{*}{1.000} & $35(92.1)$ & \multirow{2}{*}{0.710} & $13(39.4)$ & \multirow{2}{*}{0.685} \\
\hline Male & 117 & $7(6.3)$ & & 108(93.9) & & $46(43.4)$ & \\
\hline \multicolumn{8}{|l|}{ Age, years } \\
\hline$\leq 58$ (median age) & 80 & $3(3.9)$ & \multirow{2}{*}{0.318} & $72(92.3)$ & \multirow{2}{*}{0.746} & $23(32.4)$ & \multirow{2}{*}{0.017} \\
\hline$>58$ (median age) & 75 & $6(8.2)$ & & $71(94.7)$ & & $36(52.9)$ & \\
\hline \multicolumn{8}{|c|}{ Adjuvant chemotherapy } \\
\hline Yes & 129 & $6(4.8)$ & \multirow{2}{*}{0.357} & $120(94.5)$ & \multirow{2}{*}{0.375} & $50(42.7)$ & \multirow{2}{*}{1.000} \\
\hline No & 26 & $3(12.0)$ & & $23(88.5)$ & & $9(40.9)$ & \\
\hline \multicolumn{8}{|l|}{ Tumor Grade } \\
\hline Undifferentiated & 5 & $1(20)$ & \multirow{3}{*}{0.261} & $4(80.0)$ & \multirow{3}{*}{0.067} & $0(0.0)$ & \multirow{3}{*}{0.009} \\
\hline Poor & 89 & $4(4.7)$ & & $80(90.9)$ & & $28(35.0)$ & \\
\hline Moderate/well & 61 & $4(6.7)$ & & $59(98.3)$ & & $31(56.4)$ & \\
\hline \multicolumn{8}{|l|}{ Vascular invasion } \\
\hline Yes & 91 & $4(4.5)$ & \multirow{2}{*}{0.489} & $86(96.6)$ & \multirow{2}{*}{0.095} & $35(43.8)$ & 0717 \\
\hline No & 64 & $5(8.1)$ & & $57(91.9)$ & & $24(40.7)$ & 0.117 \\
\hline Nerve invasion & & & & & & & \\
\hline Yes & 91 & $4(4.5)$ & 0180 & $83(93.3)$ & 1000 & $29(37.2)$ & 0155 \\
\hline No & 64 & $5(8.1)$ & 0.409 & $60(93.8)$ & 1.000 & $30(49.2)$ & 0.153 \\
\hline $\mathrm{T}$ classificaion\# & & & & & & & \\
\hline pTis & 1 & $0(0.0)$ & & $1(100.0)$ & & $0(0.0)$ & \\
\hline pT1 & 5 & $0(0.0)$ & & $5(100.0)$ & & $3(60.0)$ & \\
\hline pT2 & 15 & $1(6.7)$ & 0.565 & $14(93.3)$ & & $6(40.0)$ & 0.617 \\
\hline pT3 & 6 & $1(16.7)$ & & $6(100.0)$ & & $4(66.7)$ & \\
\hline pT4 & 128 & $7(5.7)$ & & 117(92.9) & & $46(41.7)$ & \\
\hline $\mathrm{N}$ classificaion\# & & & & & & & \\
\hline pNo & 39 & $1(2.6)$ & & $37(94.9)$ & & $17(48.6)$ & \\
\hline pN1 & 20 & $1(5.0)$ & 0837 & $18(90.0)$ & 0635 & $8(40.0)$ & $0 \& 11$ \\
\hline $\mathrm{pN} 2$ & 36 & $3(8.3)$ & 0.831 & $35(97.2)$ & 0.035 & $13(38.2)$ & 0.841 \\
\hline $\mathrm{pN} 3$ & 60 & $4(7.1)$ & & $53(91.4)$ & & $21(42.0)$ & \\
\hline M classificaion\# & & & & & & & \\
\hline M0 & 141 & $7(5.1)$ & 0100 & $129(92.8)$ & 0600 & $54(42.5)$ & $10 \Omega 0$ \\
\hline M1 & 14 & $2(14.3)$ & 0.199 & $14(100.0)$ & 0.000 & $5(41.7)$ & 1.000 \\
\hline TNM stage\# & & & & & & & \\
\hline I & 8 & $0(0.0)$ & & $7(87.5)$ & & $2(25.0)$ & \\
\hline II & 39 & $3(7.7)$ & 0310 & $38(97.4)$ & 0348 & $20(55.6)$ & 0266 \\
\hline III & 94 & $4(4.5)$ & 0.519 & $84(91.4)$ & 0.340 & $32(38.1)$ & 0.200 \\
\hline IV & 14 & $2(14.3)$ & & $14(100.0)$ & & $5(41.7)$ & \\
\hline
\end{tabular}

ER $\alpha$, estrogen receptor alpha; ER $\beta$, estrogen receptor beta; AR, androgen receptor. \#The $7^{\text {th }}$ TNM Classification of Malignant Tumors proposed by the AJCC/UICC. * The number of patients differed between ER $\alpha$, ER $\beta$ and AR since some tissues shed off from the microarray. 
overall survival rate for ER $\alpha$-positive patients was $44.4 \%$ (4/9) compared to $59.3 \%$ (83/140) for ER $\alpha$-negative patients ( $p=0.032$; Figure $2 \mathrm{~A}$ ), while 3 -year progress free survival rate for ER $\alpha$-positive patients was $44.4 \%(4 / 9)$ compared to $53.6 \%(75 / 140)$ for ER $\alpha$-negative patients ( $p=0.103$; Figure 2D). However, ER $\beta$ expression had no significant association with overall survival (OS) ( $p=0.167$; Figure $2 \mathrm{~B}$ ) or progress free survival (PFS) ( $p=0.462$; Figure $2 \mathrm{E}$ ) of GC patients. Besides, for patients with positive AR expression, the 3 -year overall survival rate was $55.2 \%(32 / 58)$ compared to $63.8 \%$ (51/80) for AR negative patients ( $p=0.05$; Figure $2 \mathrm{C}$ ), and 3-year progress free survival rate for AR positive patients was 46.6\% (27/58) compared to $60.0 \%$ (48/80) for AR negative patients $(p=0.025$; Figure $2 \mathrm{~F})$.

Moreover, univariate analysis of OS demonstrated in Table 2 showed the significant prognostic factors for OS included $\mathrm{ER} \alpha, \mathrm{N}$ classification, $\mathrm{M}$ classification and TNM stage; AR was borderline significant associated with OS $(\mathrm{p}=0.052) . E R \alpha, \mathrm{N}$ classification and $\mathrm{M}$ classification were retained in multivariate analysis, indicating that in addition to $\mathrm{N}$ classification and $\mathrm{M}$ classification, $\mathrm{ER} \alpha$ was also an independent unfavorable factor for OS of GC patients. Table 3 demonstrated the findings of univariate and multivariate analysis of PFS. The significant prognostic factors for PFS in the univariate analysis included AR, N classification, M classification and TNM stage. However, multivariate analysis showed that AR was only borderline significant after adjustment with other variables $(\mathrm{p}=0.075)$, and $\mathrm{N}$ classification and $\mathrm{M}$ classification turned out to be independent unfavorable factors for PFS of GC patients.

\section{Downregulation of ER $\alpha$ suppressed the proliferation, migration and invasion of GC cell lines in vitro possibly through regulating the expression of p53, p21, p27, cyclin D1 and E-cadherin}

We next investigated the effects of $\mathrm{ER} \alpha$ on the malignant behavior of $\mathrm{GC}$ cells. We examined the
A
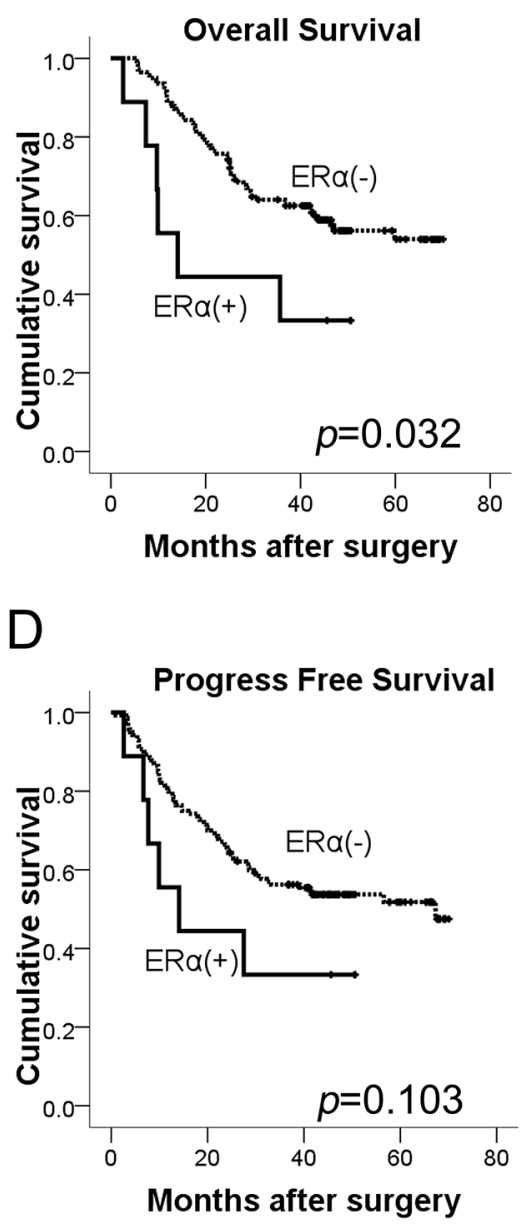

B
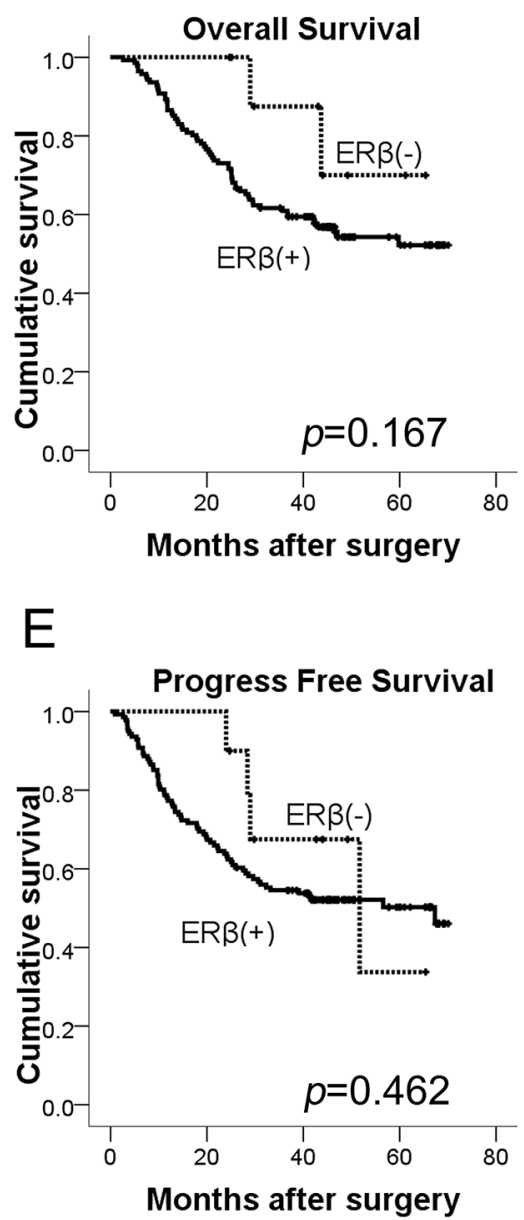

C

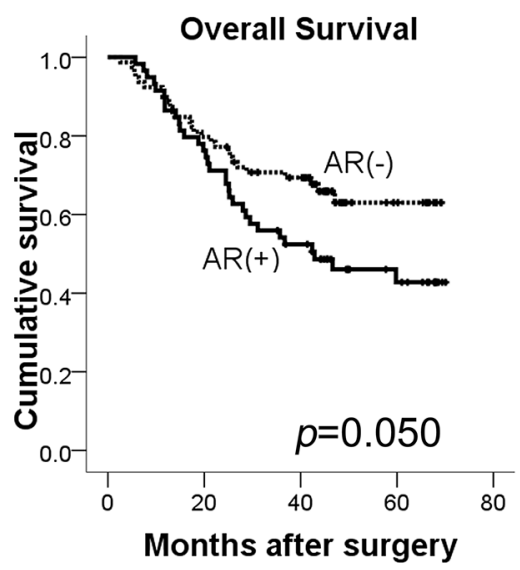

$\mathrm{F}$

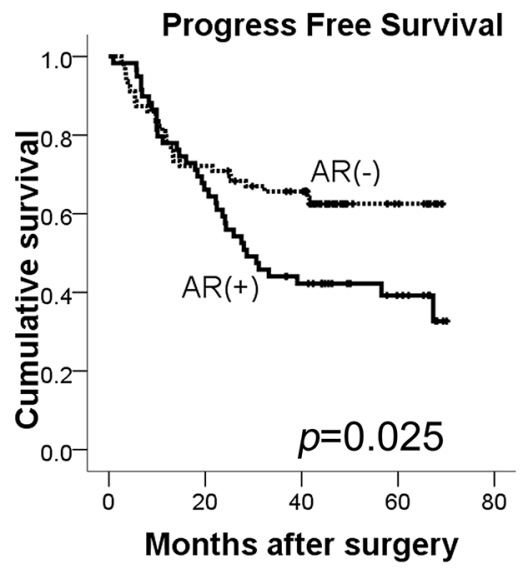

Figure 2: Kaplan-Meier curves of OS and PFS for GC patients according to (A, D) ER $\alpha,(\mathbf{B}, \mathbf{E}) \mathrm{ER} \beta,(\mathbf{C}, \mathbf{F})$ AR expression (log-rank test). OS, overall survival; PFS, progress free survival. 
Table 2: Univariate and multivariate analysis of OS by Cox model in gastric cancer

\begin{tabular}{|c|c|c|c|c|c|c|}
\hline \multirow{2}{*}{ Variable } & \multicolumn{3}{|c|}{ Univariate Cox } & \multicolumn{3}{|c|}{ Multivariate Cox } \\
\hline & HR & $95 \% \mathrm{CI}$ & $p$ & HR & $95 \% \mathrm{CI}$ & $p$ \\
\hline \multicolumn{7}{|l|}{ Sex } \\
\hline Male & 1.000 & & & & & \\
\hline Female & 1.127 & $0.635-2.002$ & 0.683 & & & \\
\hline \multicolumn{7}{|l|}{ Age, years } \\
\hline$\leq 58$ (median age) & 1.000 & & & 1.000 & & \\
\hline$>58$ (median age) & 1.165 & $0.722-1.882$ & 0.531 & 1.367 & $0.826-2.261$ & 0.224 \\
\hline \multicolumn{7}{|l|}{ Adjuvant therapy } \\
\hline No & 1.000 & & & 1.000 & & \\
\hline Yes & 1.136 & $0.580-2.226$ & 0.709 & 0.732 & $0.347-1.544$ & 0.413 \\
\hline \multicolumn{7}{|l|}{$\mathrm{T} \#$} \\
\hline pTis, pT1 & 1.000 & & & 1.000 & & \\
\hline pT2 & 0.977 & $0.189-5.036$ & 0.977 & 1.122 & $0.201-6.277$ & 0.895 \\
\hline pT3 & 2.881 & $0.527-15.754$ & 0.222 & 1.446 & $0.233-8.990$ & 0.692 \\
\hline pT4 & 1.380 & $0.336-5.658$ & 0.655 & 1.188 & $0.242-5.832$ & 0.832 \\
\hline \multicolumn{7}{|l|}{$\mathrm{N}$ classification \# } \\
\hline pN0 & 1.000 & & & 1.000 & & \\
\hline $\mathrm{pN} 1$ & 0.814 & $0.287-2.313$ & 0.700 & 0.610 & $0.210-1.777$ & 0.365 \\
\hline $\mathrm{pN} 2$ & 1.004 & $0.443-2.276$ & 0.993 & 0.673 & $0.280-1.617$ & 0.376 \\
\hline $\mathrm{pN} 3$ & 2.986 & $1.554-5.736$ & 0.001 & 2.937 & $1.487-5.799$ & 0.002 \\
\hline \multicolumn{7}{|l|}{ M classification \# } \\
\hline M0 & 1.000 & & & 1.000 & & \\
\hline M1 & 5.807 & $3.070-10.986$ & $<0.001$ & 7.906 & $3.978-15.711$ & $<0.001$ \\
\hline \multicolumn{7}{|l|}{ TNM stage } \\
\hline I & 1.000 & & & 1.000 & & \\
\hline II & 4.250 & $0.563-32.069$ & 0.161 & 4.100 & $0.563-32.069$ & 0.174 \\
\hline III & 4.114 & $0.565-29.986$ & 0.163 & 2.390 & $0.565-29.986$ & 0.399 \\
\hline IV & 22.879 & $2.956-177.050$ & 0.003 & $-*$ & $-*$ & $-*$ \\
\hline \multicolumn{7}{|l|}{$\mathrm{ER} \alpha$} \\
\hline Negative & 1.000 & & & 1.000 & & \\
\hline Positive & 2.436 & $1.050-5.651$ & 0.038 & 3.639 & $1.432-9.246$ & 0.007 \\
\hline \multicolumn{7}{|l|}{$\mathrm{ER} \beta$} \\
\hline Negative & 1.000 & & & & & \\
\hline Positive & 2.634 & $0.645-10.762$ & 0.177 & & & \\
\hline \multicolumn{7}{|l|}{$\mathrm{AR}$} \\
\hline Negative & 1.000 & & & & & \\
\hline Positive & 1.661 & $0.995-2.774$ & 0.052 & & & \\
\hline
\end{tabular}

Abbreviations: HR, hazard ratio; CI, confidence interval; ER $\alpha$, estrogen receptor alpha; ER $\beta$, estrogen receptor beta; AR, androgen receptor; OS, overall survival. \# The $7^{\text {th }}$ TNM Classification of Malignant Tumors proposed by the AJCC/UICC. *TNM stage IV is not calculated since it is linearly correlated with M classification. 
Table 3: Univariate and multivariate analysis of PFS by Cox model in gastric cancer

\begin{tabular}{|c|c|c|c|c|c|c|}
\hline \multirow{2}{*}{ Variable } & \multicolumn{2}{|c|}{ Univariate Cox } & \multirow[b]{2}{*}{$p$} & \multicolumn{2}{|c|}{ Multivariate Cox } & \multirow[b]{2}{*}{$p$} \\
\hline & HR & $95 \% \mathrm{CI}$ & & HR & $95 \%$ CI & \\
\hline \multicolumn{7}{|l|}{ Sex } \\
\hline Male & 1.000 & & & & & \\
\hline Female & 1.064 & $0.632-1.790$ & 0.861 & & & \\
\hline \multicolumn{7}{|l|}{ Age, years } \\
\hline$\leq 58$ (median age) & 1.000 & & & 1.000 & & \\
\hline$>58$ (median age) & 1.224 & $0.777-1.928$ & 0.384 & 1.209 & $0.704-2.077$ & 0.492 \\
\hline \multicolumn{7}{|l|}{ Adjuvant therapy } \\
\hline No & 1.000 & & & 1.000 & & \\
\hline Yes & 1.203 & $0.634-2.281$ & 0.572 & 0.626 & $0.291-1.347$ & 0.231 \\
\hline \multicolumn{7}{|l|}{$\mathrm{T} \#$} \\
\hline pTis, pT1 & 1.000 & & & 1.000 & & \\
\hline pT2 & 0.509 & $0.114-2.273$ & 0.509 & 0.604 & $0.125-2.912$ & 0.530 \\
\hline pT3 & 1.958 & $0.437-8.776$ & 1.958 & 0.972 & $0.164-5.743$ & 0.973 \\
\hline pT4 & 1.033 & $0.324-3.291$ & 1.033 & 1.242 & $0.296-5.218$ & 0.767 \\
\hline \multicolumn{7}{|l|}{$\mathrm{N}$ classification \# } \\
\hline $\mathrm{pN} 0$ & 1.000 & & & 1.000 & & \\
\hline $\mathrm{pN} 1$ & 0.822 & $0.316-2.141$ & 0.689 & 0.862 & $0.311-2.392$ & 0.776 \\
\hline $\mathrm{pN} 2$ & 0.861 & $0.391-1.899$ & 0.711 & 0.681 & $0.277-1.675$ & 0.402 \\
\hline $\mathrm{pN} 3$ & 2.885 & $1.573-5.291$ & 0.001 & 3.083 & $1.565-6.074$ & 0.001 \\
\hline \multicolumn{7}{|l|}{ M classification \# } \\
\hline M0 & 1.000 & & & 1.000 & & \\
\hline M1 & 6.979 & $3.724-13.079$ & $<0.001$ & 11.907 & $5.545-25.566$ & $<0.001$ \\
\hline TNM stage & 2.106 & $1.358-3.267$ & & & & \\
\hline I & 1.000 & & & 1.000 & & \\
\hline II & 2.106 & $0.483-9.175$ & 0.321 & 2.124 & $0.482-9.366$ & 0.320 \\
\hline III & 2.350 & $0.569-9.698$ & 0.237 & 1.202 & $0.278-5.198$ & 0.806 \\
\hline IV & 15.320 & $3.404-68.947$ & $<0.001$ & $-*$ & $-*$ & $-*$ \\
\hline \multicolumn{7}{|l|}{$\mathrm{ER} \alpha$} \\
\hline Negative & 1.000 & & & & & \\
\hline Positive & 1.979 & $0.856-4.573$ & 0.110 & & & \\
\hline \multicolumn{7}{|l|}{$\mathrm{ER} \beta$} \\
\hline Negative & 1.000 & & & & & \\
\hline Positive & 1.474 & $0.538-4.042$ & 0.451 & & & \\
\hline \multicolumn{7}{|l|}{$\mathrm{AR}$} \\
\hline Negative & 1.000 & & & 1.000 & & \\
\hline Positive & 1.739 & $1.065-2.840$ & 0.027 & 1.573 & $0.955-2.592$ & 0.075 \\
\hline
\end{tabular}

Abbreviations: HR, hazard ratio; CI, confidence interval; ER $\alpha$, estrogen receptor alpha; ER $\beta$, estrogen receptor beta; AR, androgen receptor; PFS, progress free survival. \# The $7^{\text {th }}$ TNM Classification of Malignant Tumors proposed by the AJCC/ UICC. *TNM stage IV is not calculated since it is linearly correlated with M classification. 
expression of ER $\alpha$ in GC cell lines, and found that ER $\alpha$ was expressed in low levels in GC cells compared with the normal gastric epithelial cell line (GES-1), which was in accordance with the low positive rate of $\mathrm{ER} \alpha$ in GC tissues examined by immunohistochemistry. MKN45 and SNU601 cells with ER $\alpha$ silenced were established by lentivirus infection, as the two cell lines showed relative high basal levels of ER $\alpha$ expression (Figure 3A). Downregulation of ER $\alpha$ was confirmed by western blot (Figure 3B). Knockdown of ER $\alpha$ significantly suppressed the proliferation of MKN45 and SNU601 cells compared with vector cells (Figure 4). Furthermore, ER $\alpha$ silenced MKN45 and SNU601 cells showed significantly decreased migration and invasion in comparison with vector cells (Figure 5).

To further explore the mechanisms in the decreased proliferation, migration and invasion by $\mathrm{ER} \alpha$ knockdown, proliferation associated molecules (p53, p21, p27, cyclin D1) as well as the important molecular in adherens junctions of epithelial cells (E-cadherin) were examined by western blot (Figure 6). The expression of p53, p21, p27 were increased in
ER $\alpha$ silenced MKN45 and SNU601 cells, as opposed to cyclin D1, which could explain the suppressed proliferation of ER $\alpha$ knockdown GC cells. In addition, increased expression of E-cadherin was observed in ER $\alpha$ silenced MKN45 and SNU601 cells, which was in accordance with the inhibited migration and invasion of ER $\alpha$ silenced MKN45 and SNU601 cells. These results suggested that downregulation of ER $\alpha$ suppressed the proliferation, migratory and invasive abilities of GC cells probably by enhancing the protein levels of p53, p21, p27 and E-cadherin and inhibiting cyclin D1 expression.

Although the present study found that AR was only borderline significantly associated with poor PFS, considering studies on the expression and function of $\mathrm{AR}$ in GC was insufficient, we also investigated the effects of AR on the malignant behavior of GC cells. AR was silenced in MGC803 and SGC7901 cells which showed relative high basal levels of AR expression by lentivirus infection (Supplementary Figure 1). No significant difference was detected in the proliferation of AR silenced cells compared to vector cells

A

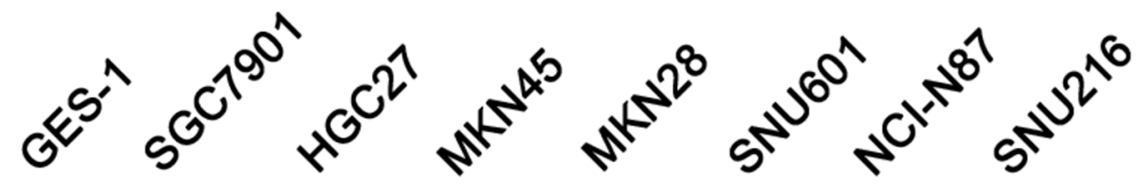

ERa

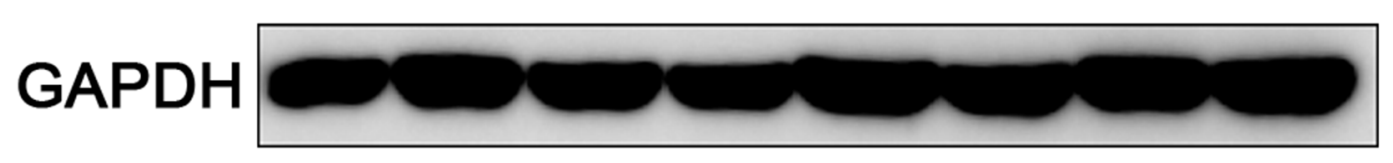

B

\section{MKN45 SNU601 shVec shERa shVec shERa} ERa
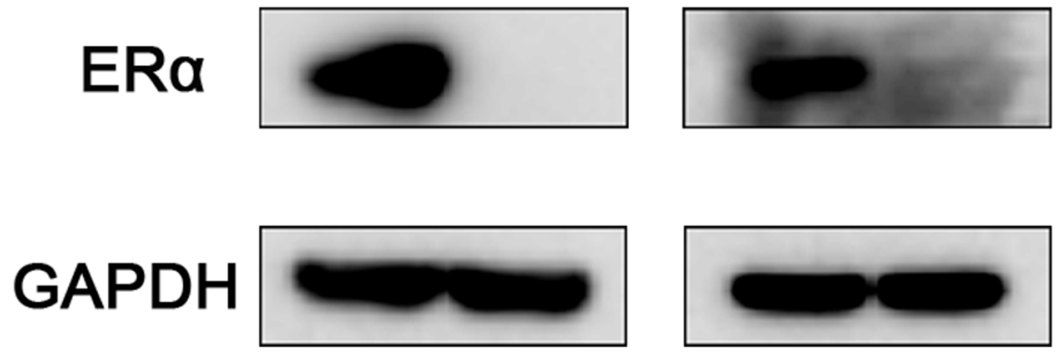

Figure 3: Expression of ER $\boldsymbol{\alpha}$ in GC cells. (A) Endogenous expression of ER $\alpha$ in the normal gastric mucosal epithelial cell (GES-1) and GC cell lines. (B) ER $\alpha$ expression was successfully silenced in MKN45 and SNU601 cells compared with corresponding vector cells. 
MKN45

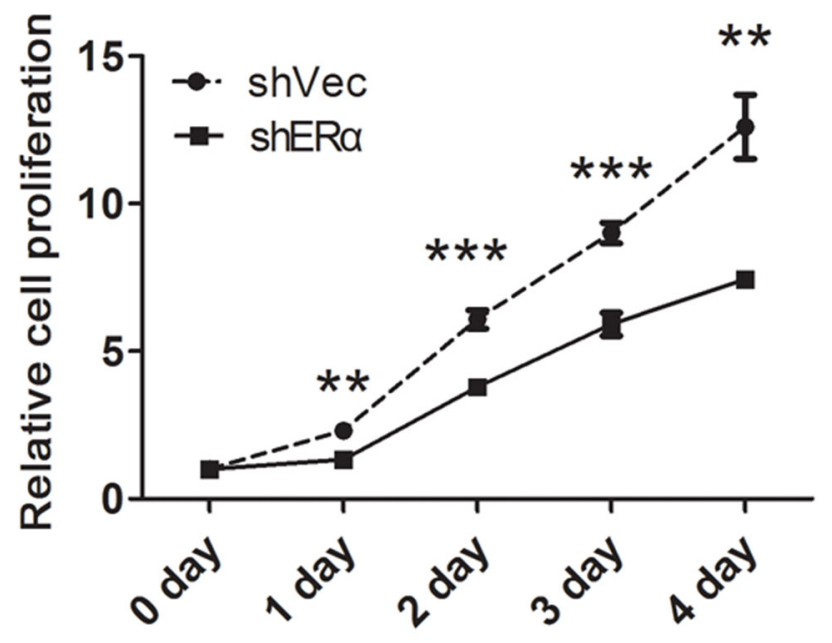

SNU601

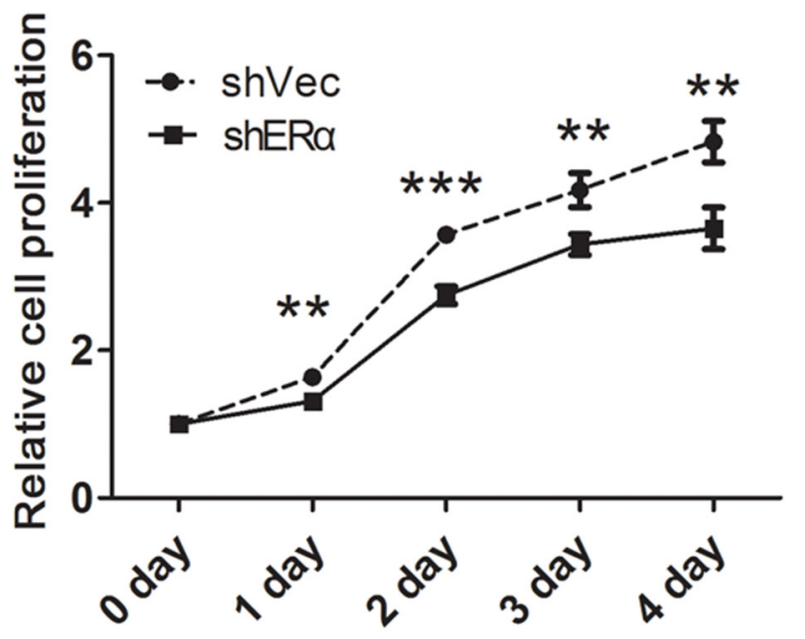

Figure 4: Downregulation of ER $\boldsymbol{\alpha}$ inhibited the proliferation of GC cells in vitro. The proliferation of GC cells was determined by Cell Counting Kit 8 (CCK8), the proliferation rate of the ER $\alpha$-silenced MKN45 and SNU601 cells was significantly suppressed compared with corresponding vector cells.
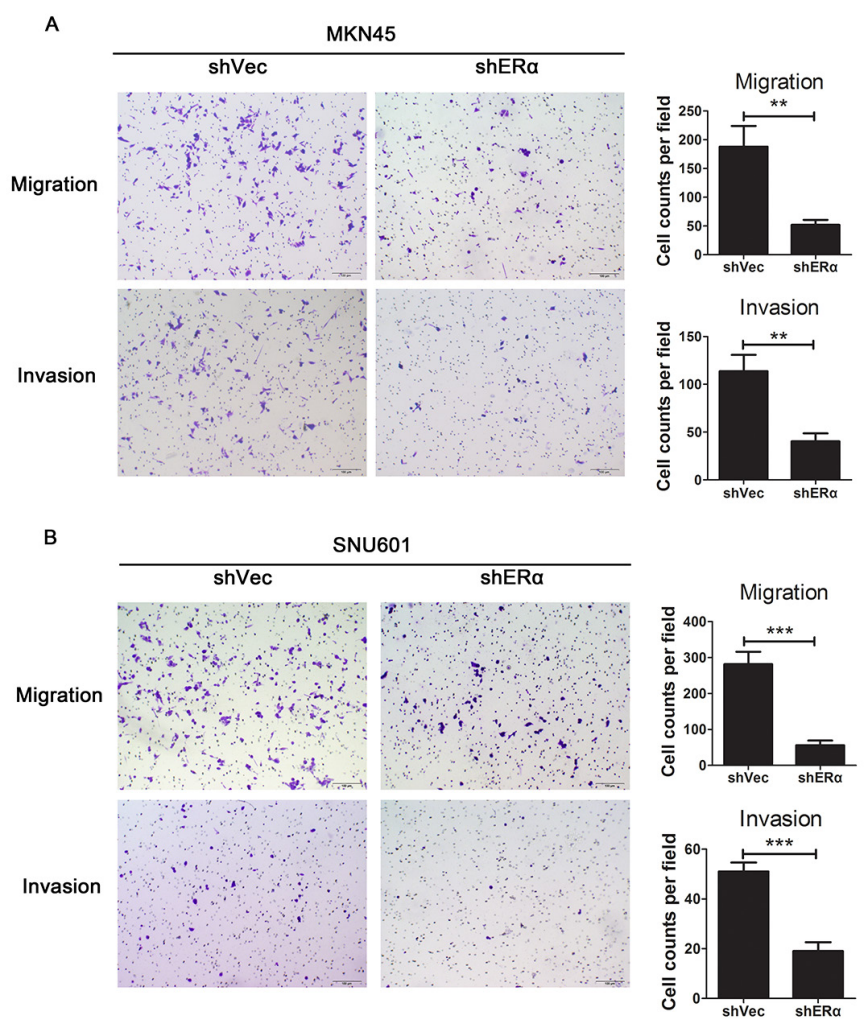

Figure 5: Downregulation of ER $\boldsymbol{E}$ suppressed the migration and invasion of GC cells in vitro. (A) Representative images for ER $\alpha$ stably downregulated or vector transfected MKN45 cells in migration and invasion assays. Numbers for cell counts per field were shown in bar graphs. (B) Representative images for ER $\alpha$ stably downregulated or vector transfected SNU601 cells in migration and invasion assays. Numbers for cell counts per field were shown in bar graphs. ${ }^{*} p<0.05 ; * * p<0.01 ; * * * p<0.001$. Results were demonstrated as mean \pm standard deviation from three independent experiments. 
(Supplementary Figure 2). However, downregulation of AR significantly suppressed the migration and invasion of MGC803 and SGC7901 cells in comparison with vector cells (Supplementary Figure 3). The expression of epithelial-mesenchymal transition (EMT) associated molecules in AR silenced and corresponding vector cells were examined by western blot (Supplementary Figure $4)$. The reduced expression of $\beta$-catenin, Alpha smooth muscle actin ( $\alpha$-SMA), snail, and slug in AR knockdown MGC803 and SGC7901 cells were in accordance with the suppressed migration and invasion of the two GC cell lines. However, E-cadherin expression was not altered in both AR downregulated cells, perhaps due to the low basal expression of E-cadherin in the two cell lines. These results indicated that downregulation of AR suppressed migratory and invasive abilities of GC cells possibly by inhibiting the EMT pathway.

\section{DISCUSSION}

The present study demonstrated $6 \%$ (9/150) of GC tissues expressed ER $\alpha, 93.5 \%$ (143/153) expressed ER $\beta$, and 42.4\% (59/139) were AR positive. The correlation coefficients among ER $\alpha, \mathrm{ER} \beta$ and AR were too small $(\mathrm{r}<$ 0.4 ), indicating that the correlation was too weak to have any clinical significance in GC. The positive expression of $\mathrm{ER} \alpha$ was an independent prognostic factor for OS, and AR was borderline associated with PFS for GC patients after adjustment with other variables. In addition, downregulation of ER $\alpha$ might suppress the proliferation, migration and invasion in vitro via regulating the expression of p53, p21, p27, cyclin D1 and E-cadherin. And AR suppressed the migration and invasion of GC cells in vitro possibly through inhibiting EMT process.

Treatment of ER positive breast cancer patients with ER antagonist has achieved great success [21]. However, whether GC can benefit from hormonal therapy remains controversial. Earlier in the 1980s, several Japanese studies found that tamoxifen administration could prolong the survival of GC patients [22-24], while an UK study demonstrated that GC patients could not benefit from tamoxifen [25]. Besides, a Korea study published in 2014 indicated that ER $\alpha$ positive GC patients had shorter PFS; Estradiol promoted the proliferation of

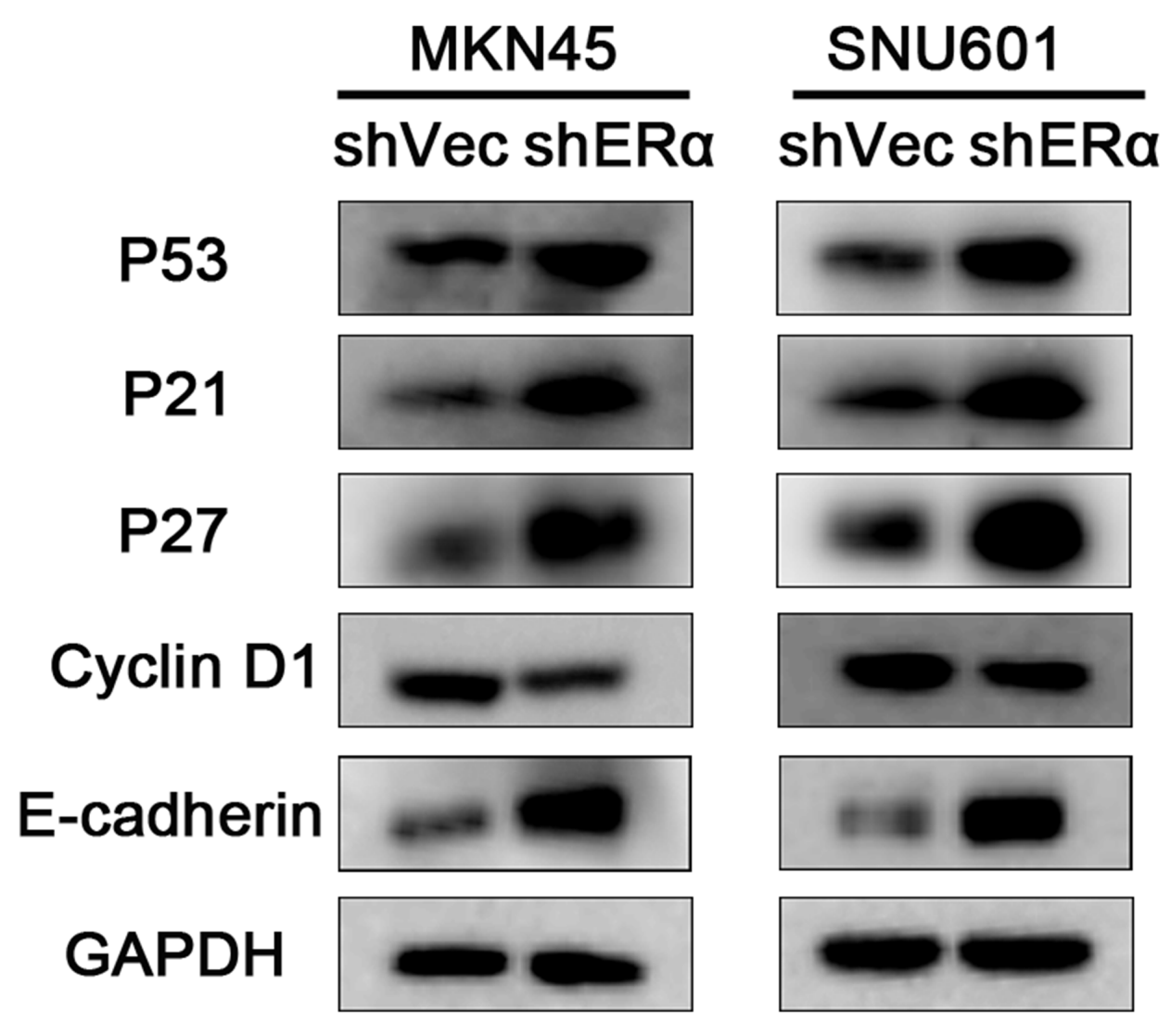

Figure 6: Downregulation of ERa suppressed the proliferation, migration and invasion of GC cells via regulating the expression of p53, p21, p27, cyclin D1 and E-cadherin. The expression of proliferation associated molecules including p53, p21, p27, and the EMT associated molecules E-cadherin were increased, while cyclin D1 was reduced in ER $\alpha$ stably downregulated MKN45 and SNU601 cells compared with corresponding vector cells. 
ER $\alpha$ positive GC cells without affecting ER $\alpha$ negative GC cells, while fulvestrant (an selective ER degrader) abrogated the enhancement of the proliferation of ER $\alpha$ positive GC cells caused by estradiol [17]. It seemed that studies done in different races drew different conclusions. Besides, ER $\alpha$ expression patterns varied in different GC patients, for example, the data from TCGA database (The Cancer Genome Atlas, https://tcga-data.nci.nih.gov/ docs/publications/tcga/) showed that among 205 stomach adenocarcinoma samples, 5 samples were detected with $E R \alpha$ amplification, 1 with deep $E R \alpha$ deletion, and 6 with $E R \alpha$ mRNA upregulation. In light of this, high-quality clinical trials that examine the effect of anti-ER therapy on the treatment of ER positive GC patients are needed, and anti-ER therapy might be only effective on ER positive individuals.

Limited researches have explored the effect of $\mathrm{ER} \alpha$ and the underlying mechanisms in GC. Several previous experimental studies has demonstrated that ER $\alpha$ could promote the proliferation of GC cells possibly by interacting with hedgehog pathway [26], c-Src pathway [27], or cyclin D1 [28], and downregulation of ER $\alpha$ could increase the expression of E-cadherin [17]. Besides, ER $\alpha$ was reported to bind p53 and inhibited the p53-mediated transcriptional activities in breast cancer $[29,30]$. On basis of the previous reports and the biological function of ER $\alpha$ revealed by the present study, we examined the expression of several crucial proliferation associated proteins and the important EMT associated protein (E-cadherin), and found enhanced p53, p21, p27 and E-cadherin expression and decreased cyclin D1 expression in ER $\alpha$ silenced GC cells. P53, a typical tumor suppressor protein, is capable of modulating the transcription of various target genes, such as p21 [29]. P21 and p27 are important cell cycle inhibitors which can prevent the activation of cyclindependent kinases including cyclin D/CDK complex [31]. E-cadherin is a crucial protein in maintaining the cell-cell adhesion, loss of which can initiate EMT process [32]. Taken together, knockdown of ER $\alpha$ could suppress the proliferation, migration and invasion of GC cells possibly via modulating the expression of p53, p21, p27, cyclin D1 and E-cadherin.

Since the prognostic role of AR in GC and the potential mechanisms are insufficient, even though the association of AR with PFS only reached borderline significance in the present study, we performed in vitro experiment, and revealed that downregulation of AR suppressed the migratory and invasive ability of GC cells, possibly via inhibition of EMT associated molecules including $\alpha$-SMA, $\beta$-catenin, snail, and slug. In fact, Kominea et al firstly reported that AR was an unfavorable prognostic factor for the OS of GC patients [19]. Later Zhang et al examined the expression of AR with a relatively small sample size and showed that AR expression was associated with more lymph node metastasis and later TNM stage, and demonstrated that AR could promote GC metastasis by upregulating MMP9 [20]. Taken together with findings of those two studies and our study, positive AR expression might be an unfavorable factor for the survival of GC patients.

In summary, the present study showed that positive expression of ER $\alpha$ was significantly associated and positive expression of AR had a tendency to associate with poor prognosis of Chinese GC patients. In addition, knockdown of ER $\alpha$ suppressed the proliferation, migration and invasion of GC cells probably via modulating the expression of p53, p21, p27, cyclin D1 and E-cadherin. And downregulation of AR suppressed the migration and invasion of GC cells possibly via inhibiting EMT process. The results suggested that ER $\alpha$ and AR might serve as prognostic biomarkers and therapeutic targets to improve the survival of Chinese GC patients. In the next period of time, precise approaches are needed to identify the expression patterns of ER $\alpha$ and AR in GC patients, and clinical trials involving highly selected ER $\alpha$ and AR positive patients are required to illustrate the potential of anti-ER $\alpha$ and anti-AR therapy in GC.

\section{MATERIALS AND METHODS}

\section{Patients and clinicopathological data}

Formalin-fixed and paraffin-embedded tumor tissues were collected from 155 patients with gastric carcinoma who underwent surgical resection at the Department of Gastric Cancer and Soft Tissue Sarcomas, Shanghai Cancer Center of Fudan University, Shanghai, China, from Oct 2007 to Jan 2010. The samples were used for tissue microarray construction and immunohistochemistry. The patients were followed up every 4 months until death or the end of the study (September 2nd, 2013), except those lost to follow up. Overall survival (OS) was defined as the interval between the date of surgery and the date of death or last follow-up visit. Progress free survival (PFS) was defined as the time from the date of surgery to the time of disease progression, death, or last follow-up visit if the disease did still not progress.

Informed consents were obtained from all patients, and the research was approved by the Clinical Research Ethics Committee of Fudan University Shanghai Cancer Center, and complied with the principles of the Helsinki Accord.

\section{Immunohistochemistry}

$\mathrm{ER} \alpha, \mathrm{ER} \beta$ and AR expression was detected by immunohistochemistry using UltraSensitive ${ }^{\mathrm{TM}}$ SP kit (\#9710, Maixin, Fuzhou, China) according to the manufacturer's instructions. In brief, the sections were deparaffinized, rehydrated and subjected to antigen 
retrieval (citrate buffer, $\mathrm{pH}=6.0$ ). The sections were then incubated overnight at $4^{\circ} \mathrm{C}$ with the primary mouse monoclonal antibodies to $\mathrm{ER} \alpha$ (clone 33, ab2746, Abcam; 1:50), ER $\beta$ (clone 14C8, ab288, Abcam; 1:100) and AR (clone AR 441, ab9474, Abcam; 1:200), respectively. The sections were subsequently washed and incubated with a secondary antibody. Reaction products were visualized with 3, 3'diaminobenzidine tetrahydrochloride and counterstained with hematoxylin and eosin.

\section{Staining evaluation}

Cases displaying brown cytoplasmic and/or nuclear stainings were regarded as positive. The staining intensity was graded by the Allred score system [33]. A score $\geq 3$ was considered as positive and a score less than 3 was designated as negative. The immunoreactivity was viewed by two pathologists independently.

\section{Cell culture}

Nine human GC cell lines (MGC803, AGS, SGC7901, HGC27, MKN45, MKN28, SNU601, NCI-N87, SNU216), one normal gastric epithelial cell line (GES1) and HEK293T cell line were obtained from the Cell Resource Center, Shanghai Institute of Biochemistry and Cell Bank at the Chinese Academy of Sciences. All cell lines were routinely authenticated by DNA-fingerprinting and isoenzyme analysis and free of contamination by mycoplasma. GC cell lines were cultured in RPMI 1640, MEM, or DMEM containing 10\% fetal bovine serum at 37 ${ }^{\circ} \mathrm{C}$ under humidified atmosphere with $5 \% \mathrm{CO} 2$.

\section{Lentivirus production and transduction}

Lentiviral vector expressing shRNA targeting ER $\alpha$ was purchased from Obio Tech (Shanghai, China), and lentiviral vector expressing shRNA targeting AR was purchased from Genechem (Shanghai, China). Those shRNAs were transfected into HEK293T cells using FuGene ${ }^{\circledR}$ HD Transfection Reagent (Promega) to generate lentivirus. MKN45, SNU601, MGC803 and SGC7901 cells were infected with the recombinant lentivirus with $10 \mu \mathrm{g} / \mathrm{mL}$ Polybrene ${ }^{\circledR}$ (Sigma-Aldrich, St Louis, MO, USA).

\section{Cell proliferation assays}

MKN45 and SNU601 cells were plated at a density of 2000 cells per well in 96-well plates. MGC803 and SGC7901 cells were plated at a density of 1000 cells per well in 96-well plates. Cell proliferation was determined with Cell Counting Kit 8 (CCK8, Dojindo, Kumamoto, Japan) for 5 days.

\section{Cell migration and invasion assays}

Migration and invasion assays in vitro were carried out in chambers of $8-\mu \mathrm{m}$ transwell inserts (BD Falcon ${ }^{\mathrm{TM}}$; Becton Dickinson, Franklin Lakes, NJ, USA) in the presence or absence of Matrigel (BD Falcon ${ }^{\mathrm{TM}}$ ). Eighty thousand MKN45 and SNU601 cells, 40,000 MGC803 cells and 60,000 SGC7901 cells were seeded in the top chamber in serum-free medium, while medium containing $20 \%$ serum was in the lower chamber as the attractant. After 24-48 hours, migrated cells were fixed with 4\% paraformaldehydeand then stained with $0.1 \%$ crystal violet. The number of migrated cells was counted using an IX71 inverted microscope (Olympus Corp, Tokyo, Japan).

\section{Western blot}

Cells were lysed and the protein concentration was measured using the bicinchoninic acid protein assay kit (Biyotime, Shanghai, China). The lysates were subjected to SDS-PAGE gel and transferred to a PVDF membrane (Millipore, Billerica, USA). The membrane were blocked with 5\% non-fat milk and incubated with indicated primary antibodies, and then probed with the horseradish peroxidaseconjugated secondary antibody. The primary antibodies against ER $\alpha$ was purchased from Abcam. The primary antibodies against p53 and p27 were purchased from Santa Cruz Biotechnology. The primary antibodies against p21 were purchased from Abways Technology. The primary antibodies against AR, snail, slug, $\alpha$-SMA, and $\beta$-catenin were purchased from Cell Signaling Technology. The antibody against GAPDH was purchased from Proteintech Group. The blots were visualized with Pierce ${ }^{\mathrm{TM}}$ enhanced chemiluminescence reagents (Life Technologies).

\section{Statistical analysis}

The associations of $\mathrm{ER} \alpha, \mathrm{ER} \beta$ and AR expression with clinicopathological characteristics were evaluated by Chi-square test or Fisher's exact test. Survival data were analyzed using Kaplan-Meier method (log-rank test). Cox proportional hazards was used for univariate and multivariate survival analysis, clinical factors considered relevant for the prognosis including age, adjuvant therapy, TNM classification and stage according to the REMARK criteria [34], as well as other significant $(p<0.05)$ factors in the univariate analysis were allowed to enter multivariate analysis, and a reduced model was applied using stepwise backward elimination until only significant $(p<0.05)$ variables remained in multivariate survival analysis. The data of functional experiments were expressed as the mean \pm standard deviation from three independent experiments, and analyzed using Student's $t$-test. All statistical analyses were performed by the SPSS 19.0 for windows (SPSS Inc, 
Chicago, IL, USA). A two-tailed $p<0.05$ was considered statistically significant.

\section{Abbreviations}

ER, estrogen receptor; AR, androgen receptor; GC, gastric cancer.

\section{ACKNOWLEDGMENTS}

The authors thank Prof Jin Li for administrative support, and the Tissue Bank of Fudan University Shanghai Cancer Center for the help with tumor sample collection; and Shanghai Biochip Co. Ltd., for assistance with tissue microarray construction.

\section{CONFLICTS OF INTEREST} interests.

The authors declare that they have no competing

\section{FUNDING}

This work was supported by the Natural Science Foundation of Shanghai (grant no. 15ZR1407900).

\section{REFERENCES}

1. Torre LA, Bray F, Siegel RL, Ferlay J, Lortet-Tieulent J, Jemal A. Global cancer statistics, 2012. CA: a cancer journal for clinicians. 2015; 65:87-108.

2. Bang YJ, Van Cutsem E, Feyereislova A, Chung HC, Shen L, Sawaki A, Lordick F, Ohtsu A, Omuro Y, Satoh $\mathrm{T}$. Trastuzumab in combination with chemotherapy versus chemotherapy alone for treatment of HER2-positive advanced gastric or gastro-oesophageal junction cancer (ToGA): a phase 3, open-label, randomised controlled trial. The Lancet. 2010; 376:687-697.

3. Ceresoli GL, De Vincenzo F, Sauta MG, Bonomi M, Zucali PA. Role of chemotherapy in combination with hormonal therapy in first-line treatment of metastatic hormonesensitive prostate cancer. The quarterly journal of nuclear medicine and molecular imaging. 2015; 59: 374-80.

4. Hurvitz SA, Pietras RJ. Rational management of endocrine resistance in breast cancer: a comprehensive review of estrogen receptor biology, treatment options, and future directions. Cancer. 2008; 113:2385-2397.

5. Tokunaga A, Kojima N, Andoh T, Matsukura N, Yoshiyasu M, Tanaka N, Ohkawa K, Shirota A, Asano G, Hayashi K. Hormone receptors in gastric cancer. European journal of cancer \& clinical oncology. 1983; 19:687-689.

6. Harrison J, Morris D, Ellis I, Jones J, Jackson I. The effect of tamoxifen and estrogen receptor status on survival in gastric carcinoma. Cancer. 1989; 64:1007-1010.
7. Matsui M, Kojima O, Kawakami S, Uehara Y, Takahashi $\mathrm{T}$. The prognosis of patients with gastric cancer possessing sex hormone receptors. Surgery today. 1992; 22:421-425.

8. Machado J, Carneiro F, Gärtner F, Ribeiro P, SobrinhoSimões M. Female sex hormone receptors are not involved in gastric carcinogenesis. A biochemical, immunohistochemical study. European Journal of Cancer Prevention. 1994; 3:31-38.

9. Takano N, Iizuka N, Hazama S, Yoshino S, Tangoku A, Oka M. Expression of estrogen receptor- $\alpha$ and- $\beta$ mRNAs in human gastric cancer. Cancer letters. 2002; 176:129-135.

10. Matsuyama S, Ohkura Y, Eguchi H, Kobayashi Y, Akagi K, Uchida K, Nakachi K, Gustafsson JÅ, Hayashi SI. Estrogen receptor $\beta$ is expressed in human stomach adenocarcinoma. Journal of cancer research and clinical oncology. 2002; 128:319-324.

11. Wang M, Pan JY, Song GR, Chen HB, An LJ, Qu SX. Altered expression of estrogen receptor alpha and beta in advanced gastric adenocarcinoma: correlation with prothymosin alpha and clinicopathological parameters. European Journal of Surgical Oncology. 2007; 33:195-201.

12. Chandanos E, Rubio CA, Lindblad M, Jia C, Tsolakis $\mathrm{AV}$, Warner M, Gustafsson JÅ, Lagergren J. Endogenous estrogen exposure in relation to distribution of histological type and estrogen receptors in gastric adenocarcinoma. Gastric Cancer. 2008; 11:168-174.

13. Chandanos E, Lagergren J. Oestrogen and the enigmatic male predominance of gastric cancer. European journal of cancer. 2008; 44:2397-2403.

14. Xu C, Guo J, Jiang Z, Xie S, Shen J, Shen J, Wang L. Prognostic role of estrogen receptor $\alpha$ and estrogen receptor $\beta$ in gastric cancer. Annals of surgical oncology. 2010; 17:2503-2509.

15. Zhou J, Teng R, Xu C, Wang Q, Guo J, Xu C, Li Z, Xie $\mathrm{S}$, Shen J, Wang L. Overexpression of ER $\alpha$ inhibits proliferation and invasion of MKN28 gastric cancer cells by suppressing $\beta$-catenin. Oncology reports. 2013; 30:1622-1630.

16. Qin J, Liu M, Ding Q, Ji X, Hao Y, Wu X, Xiong J. The direct effect of estrogen on cell viability and apoptosis in human gastric cancer cells. Molecular and cellular biochemistry. 2014; 395:99-107.

17. Yi JH, Do IG, Jang J, Kim ST, Kim KM, Park SH, Park JO, Park YS, Lim HY, Kang WK. Anti-tumor efficacy of fulvestrant in estrogen receptor positive gastric cancer. Scientific reports. 2014; 4.

18. Gan L, He J, Zhang X, Zhang YJ, Yu GZ, Chen Y, Pan J, Wang JJ, Wang X. Expression profile and prognostic role of sex hormone receptors in gastric cancer. BMC cancer. 2012; $12: 566$.

19. Kominea A, Konstantinopoulos P, Kapranos N, Vandoros G, Gkermpesi M, Andricopoulos P, Artelaris S, Savva S, Varakis I, Sotiropoulou-Bonikou G. Androgen receptor (AR) expression is an independent unfavorable prognostic 
factor in gastric cancer. Journal of cancer research and clinical oncology. 2004; 130:253-258.

20. Zhang BG, Du T, Ming-de Zang QC, Fan ZY, Li JF, Yu BQ, Su LP, Li C, Yan C, Gu QL. Androgen receptor promotes gastric cancer cell migration and invasion via AKT-phosphorylation dependent upregulation of matrix metalloproteinase 9. Oncotarget. 2014; 5:10584. doi: 10.18632/oncotarget.2513

21. Sommer S, Fuqua SA. Estrogen receptor and breast cancer. Semin Cancer Bio. 2001; 11:339-52.

22. Kitaoka H. Sex hormone dependency in diffuse carcinoma of the stomach and results of chemo-endocrine therapy. [Aricle in Japanese] Gan no rinsho Japan journal of cancer clinics. 1984; 30:741-748.

23. Kitaoka H. Sex hormone dependency and endocrine therapy in diffuse carcinoma of the stomach. [Aricle in Japanese] Cancer \& chemotherapy. 1983; 10:2453-2460.

24. Kojima O, Takahashi T. Endocrine therapy of scirrhous carcinoma of the stomach. [Aricle in Japanese] Cancer \& chemotherapy. 1986; 13:2526-2531.

25. Harrison JD, Morris DL, Ellis IO, Jones JA, Jackson I. The effect of tamoxifen and estrogen receptor status on survival in gastric carcinoma. Cancer. 1989; 64:1007-1010.

26. Kameda C, Nakamura M, Tanaka H, Yamasaki A, Kubo M, Tanaka M, Onishi H, Katano M. Oestrogen receptor-alpha contributes to the regulation of the hedgehog signalling pathway in ERalpha-positive gastric cancer. British journal of cancer. 2010; 102:738-747.

27. Wang X, Deng H, Zou F, Fu Z, Chen Y, Wang Z, Liu L. ER-alpha36-mediated gastric cancer cell proliferation via the c-Src pathway. Oncology letters. 2013; 6:329-335.
28. Wang X, Huang X, Fu Z, Zou F, Li Y, Wang Z, Liu L. Biphasic ER-alpha36-mediated estrogen signaling regulates growth of gastric cancer cells. International journal of oncology. 2014; 45:2325-2330.

29. Liu W, Konduri SD, Bansal S, Nayak BK, Rajasekaran SA, Karuppayil SM, Rajasekaran AK, Das GM. Estrogen receptor-alpha binds $\mathrm{p} 53$ tumor suppressor protein directly and represses its function. The Journal of biological chemistry. 2006; 281:9837-9840.

30. Sayeed A, Konduri SD, Liu W, Bansal S, Li F, Das GM. Estrogen receptor alpha inhibits p53-mediated transcriptional repression: implications for the regulation of apoptosis. Cancer research. 2007; 67:7746-7755.

31. Dai M, Al-Odaini AA, Fils-Aime N, Villatoro MA, Guo J, Arakelian A, Rabbani SA, Ali S, Lebrun JJ. Cyclin D1 cooperates with $\mathrm{p} 21$ to regulate TGFbeta-mediated breast cancer cell migration and tumor local invasion. Breast cancer research. 2013; 15:R49.

32. Liu X, Chu KM. E-cadherin and gastric cancer: cause, consequence, and applications. BioMed research international. 2014; 2014:637308.

33. Allred DC, Clark GM, Elledge R, Fuqua SA, Brown RW, Chamness GC, Osborne CK, McGuire WL. Association of p53 protein expression with tumor cell proliferation rate and clinical outcome in node-negative breast cancer. Journal of the National Cancer Institute. 1993; 85:200-206.

34. McShane LM, Altman DG, Sauerbrei W, Taube SE, Gion M, Clark GM and Statistics Subcommittee of the NCIEWGoCD. Reporting recommendations for tumor marker prognostic studies (REMARK). Journal of the National Cancer Institute. 2005; 97:1180-1184. 